


\section{Marktwaarde van dieren bij dierziektebestrijding}

R.H.M Bergevoet, L. Puister-Jansen

Dit onderzoek is uitgevoerd door Wageningen Economic Research in opdracht van en gefinancierd door het ministerie van Landbouw, Natuur en Voedselkwaliteit, in het kader van het Beleidsondersteunend onderzoek KD-2019-088 Marktwaarde diverse diersoorten BO-43 Duurzame voedselvoorziening \& -productieketens \& Natuur (projectnummer) BO-43-014.01-054

Wageningen Economic Research

Wageningen, April 2020

NOTA

2020-038 
Bergevoet, R.H.M., L. Puister-Jansen, 2020. Marktwaarde van dieren bij dierziektebestrijding. Wageningen, Wageningen Economic Research, Nota 2020-038. 18 blz.; 0 fig.; 4 tab.; 36 ref.

$\mathrm{Er}$ is weinig inzicht in de marktwaarde van een aantal diersoorten waarvoor schadevergoeding nodig kan zijn in het geval van doden van dieren in het kader van dierziektebestrijding.

Voor de meeste landbouwhuisdieren wordt de waarde bepaald aan de hand van waardetabellen. Er is echter aanvullend inzicht nodig voor dieren die niet onder de waardetabellen vallen. Naast inzicht in de meest voorkomende waarde (modus) geeft deze publicatie ook inzicht in relatief extreme waarden van dieren (zowel voor de landbouwhuisdieren als voor een aantal andere diersoorten). Dit onderzoek betreft de volgende dieren: die landbouwhuisdieren die niet onder waardetabellen vallen, paarden, honden en postduiven en een aantal bijzondere diersoorten (vogels, evenhoevigen).

Insight is lacking into the market value of a number of animal species that require compensation in the case of compulsory culling in the context of animal disease control. For the major farm animal species, the valuation of most animals can be based on value tables. However, additional insight is needed for animals that do not fall under the value tables. In addition to insight into the most common value (mode), this publication provides the value of very valuable animals (both for farm animals as well as for a number of additional species). The market value of the following species is addressed: farm animals, horses, dogs and carrier pigeons and a number of special animal species (ornamental birds, cloven-hoofed zoo animals).

Trefwoorden: diergezondheid, dierziektebestrijding, marktwaarde

Dit rapport is gratis te downloaden op https://doi.org/10.18174/520051 of op www.wur.nl/economicresearch (onder Wageningen Economic Research publicaties).

(C) 2020 Wageningen Economic Research

Postbus 29703, 2502 LS Den Haag, T 07033583 30, E communications.ssg@wur.nl, www.wur.nl/economic-research. Wageningen Economic Research is onderdeel van Wageningen University \& Research.

\section{(cc) BY-NC}

Dit werk valt onder een Creative Commons Naamsvermelding-Niet Commercieel 4.0 Internationaallicentie.

(C) Wageningen Economic Research, onderdeel van Stichting Wageningen Research, 2020 De gebruiker mag het werk kopiëren, verspreiden en doorgeven en afgeleide werken maken. Materiaal van derden waarvan in het werk gebruik is gemaakt en waarop intellectuele eigendomsrechten berusten, mogen niet zonder voorafgaande toestemming van derden gebruikt worden. De gebruiker dient bij het werk de door de maker of de licentiegever aangegeven naam te vermelden, maar niet zodanig dat de indruk gewekt wordt dat zij daarmee instemmen met het werk van de gebruiker of het gebruik van het werk. De gebruiker mag het werk niet voor commerciële doeleinden gebruiken.

Wageningen Economic Research aanvaardt geen aansprakelijkheid voor eventuele schade voortvloeiend uit het gebruik van de resultaten van dit onderzoek of de toepassing van de adviezen.

Wageningen Economic Research is ISO 9001:2015 gecertificeerd. 


\section{Inhoud}

1

$\begin{array}{ll}\text { Inleiding } & 5\end{array}$

1.1 Achtergrond $\quad 5$

1.1.1 Probleemstelling 6

$\begin{array}{ll}1.1 .2 \text { Projectdoelstelling } & 6\end{array}$

$\begin{array}{lll}2 & \text { Methode } & 7\end{array}$

2.1 Het concept marktwaarde $\quad 7$

$\begin{array}{lll}2.2 & \text { Waarderingsgrondslag en onderzochte diersoorten } & 7\end{array}$

$\begin{array}{lll}2.3 \text { Databronnen } & 9\end{array}$

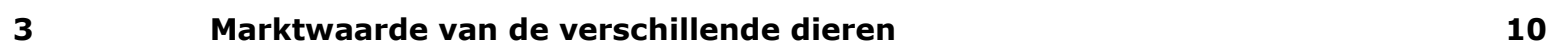

3.1 Landbouwhuisdieren $\quad 10$

3.1.1 Rundvee 10

3.1.2 Varkens 10

3.1 .3 Pluimvee 11

3.1.4 Paarden 11

3.2 Bijzondere diersoorten (honden, vogels, evenhoevigen) 13

3.2.1 Honden 13

3.2.2 Postduiven 14

$\begin{array}{ll}\text { 3.2.3 Marktwaarde van siervogels } & 14\end{array}$

3.2.4 Marktwaarde van dierentuindieren 14

4

$\begin{array}{ll}\text { Samenvattend } & 15\end{array}$

$\begin{array}{ll}\text { Literatuur en websites } & 16\end{array}$ 



\section{$1 \quad$ Inleiding}

\section{$1.1 \quad$ Achtergrond}

In Nederland worden dierziekten bestreden door de houder van de dieren, houders gezamenlijk of door de overheid. Op basis van een categorisatie van de dierziekten wordt duidelijk wie, bij welke dierziekten, de bestrijding uitvoert. Dierziektepreventie en bestrijding door de overheid wordt door EU-regelgeving (richtlijnen, verordeningen en besluiten) en Nederlandse wetgeving bepaald. De Gezondheids- en welzijnswet voor dieren (Gwwd) biedt hiervoor de wettelijke basis.

Per 21 april 2021 zal alle diergezondheidsregelgeving in Nederland op basis van de Wet Dieren in werking treden. Dit is inclusief de regelgeving voor schadevergoeding aan dierhouders in geval van doden van dieren. De huidige diergezondheidsregels, die op de Gwwd gebaseerd zijn, worden ingetrokken. Daar waar er nationale regelgeving nodig is om de nieuwe Europese diergezondheidsverordening (DGV) (of Animal health regulation (AHR) (EU a, 2020)) uit te voeren of waar aanvullende nationale regelgeving noodzakelijk is, wordt die gebaseerd op de Wet Dieren.

(Overheid.nl, 2020).

Voor bepaalde dierziekten, zoals mond- en klauwzeer of rabiës, geldt nationale en Europese regelgeving die lidstaten verplicht om dieren die besmet of verdacht zijn te doden. In het geval de overheid dergelijke dieren doodt, krijgt de houder van de dieren een tegemoetkoming voor de schade op basis van een getaxeerde marktwaarde van die dieren. Tijdens de bestrijding van een besmettelijke dierziekte is het van groot belang voor zowel eigenaren als de overheid om te komen tot een juiste bepaling van de marktwaarde van de dieren die in het kader van georganiseerde dierziektebestrijding gedood worden.

Voor landbouwhuisdieren zijn waardetabellen opgesteld als leidraad voor de taxateur bij de bepaling van de marktwaarde bij overname van dieren. In overleg met het ministerie van Landbouw, Natuur en Voedselkwaliteit (LNV) en de betreffende veehouderijsectoren worden deze waardetabellen elk jaar geactualiseerd. De waardetabellen zijn zo ingericht dat ze tijdens een dierziektecrisis snel kunnen worden geactualiseerd waarbij rekening kan worden gehouden met de actuele marktprijzen. Er zijn waardetabellen opgesteld voor de volgende diercategorieën:

- pluimvee

- varkens

- vleeskalveren

- melkvee

- melkgeiten

- vleesschapen.

Er is echter aanvullend inzicht in de marktwaarde nodig voor dieren die niet onder deze tabellen vallen.

Onder de Wet Dieren is het mogelijk de schadevergoeding te maximeren die aan getroffen eigenaren betaald wordt indien de overheid besluit tot overname van dieren in het kader van dierziektebestrijding. Dit gebeurt om onredelijke belasting van het diergezondheidsfonds en de financiële reserves van de overheid te voorkomen. Om een eventuele maximering te kunnen onderbouwen is feitelijke informatie over marktwaarden van de verschillende diersoorten nodig. 


\subsubsection{Probleemstelling}

$\mathrm{Er}$ is meer inzicht nodig in de marktwaarde van een aantal diersoorten die in het kader van de bestrijding van bestrijding plichtige dierziekten gedood moeten worden en waarbij schadevergoeding nodig is. Daarbij wordt inzicht gevraagd in de verdeling van de markwaarde binnen de populatie evenals de meest voorkomende waarde. Er is ook inzicht nodig in de waarde van zeer waardevolle dieren (extreme waarden).

\subsubsection{Projectdoelstelling}

De doelstelling is het geven van inzicht in de marktwaarde van dieren die in het kader van het bestrijden van een dierziekte gedood zouden moeten worden. Dit betreft de volgende diersoorten: landbouwhuisdieren voor zover niet geregeld via de waardetabellen, paarden, honden, postduiven en een aantal bijzondere diersoorten (vogels en diverse dierentuindieren). 


\section{$2 \quad$ Methode}

\section{$2.1 \quad$ Het concept marktwaarde}

Op grond van EU-verordening 652/2014 draagt de EU bij aan de kosten die door de overheid gemaakt zijn in het kader van dierziektebestrijding (EU b, 2020). Hieronder valt ook een bijdrage aan de kosten in verband met tegemoetkoming in de schade aan eigenaren van wie de dieren zijn gedood. Deze tegemoetkoming is beperkt tot de marktwaarde van de dieren.

Marktwaarde is de prijs die de eigenaar normaal gesproken voor het dier had kunnen krijgen in een normale handelsmarkt onmiddellijk voordat het besluit werd genomen om het te doden, te vernietigen of te slachten, vanwege de aanwezigheid van de ziekte of infectie. Deze prijs houdt rekening met de gezondheidsstatus, leeftijd en kwaliteit van het dier, zonder aftrek van waardeverlies door het optreden van de ziekte of de infectie.

\subsection{Waarderingsgrondslag en onderzochte diersoorten}

Voor het vaststellen van de waarde van dieren helpt het als er voor de te waarderen dieren een markt is waarbij vergelijkbare dieren verhandeld worden. Indien deze aanwezig is, wordt de waarde van dergelijke dieren als waarde aangenomen. Voor een aantal categorieën van dieren die in het kader van dierziektebestrijding worden gecompenseerd zijn er geen markten waarbij dieren van vergelijkbare leeftijden en/of gebruiksmogelijkheden verhandeld worden. Ook is het vaststellen van de verkoopwaarde van speciale waardevolle dieren moeilijk. De reden dat het bepalen van de marktwaarde van deze dieren moeilijk is, is dat dergelijke dieren niet regelmatig verkocht worden en als ze verkocht worden dan is er:

- veel directe (onderhandse) handel tussen koper en verkoper zodat dat dier niet via een markt verkocht wordt

- beperkte bereidheid van zowel koper als verkoper om feitelijke informatie te delen

- alleen indirecte informatie (vakbladen/internetsites) beschikbaar en worden alleen extremen gemeld

- sprake van vraagprijzen in plaats van verkoopprijzen.

Bepaalde dieren worden nooit verkocht maar geruild zoals bij dierentuindieren of in beheer gegeven zoals hulphonden.

Om toch inzicht te krijgen in de marktwaarde van deze diersoorten is gebruikgemaakt van een inventarisatie van bestaande bronnen en expertconsultatie. In deze studie hebben we onderzoek gedaan naar de marktwaarde van de hierna genoemde groepen.

\section{Landbouwhuisdieren}

De meest voorkomende diergroepen zijn beschreven in de waardetabellen. In deze notitie beperken we ons tot de marktwaarde van hoogwaardige fokdieren.

- Vrouwelijk hoogwaardig fokvee: deze dieren worden incidenteel verkocht (onderhands) en via veilingen

- Mannelijk fokdieren van vleesvee: deze dieren worden net als vrouwelijk fokvee onderhands verkocht. KI-stieren worden als kalfje vaak aangekocht door een KI-organisatie. Handel in volwassen dieren is zeer ongebruikelijk. 


\section{Paarden}

Paarden van verschillende leeftijden, rassen en kwaliteiten worden vaker verhandeld. Dit kan gebeuren via direct contact tussen koper en verkoper of via tussenkomst van een intermediair. Daarnaast neemt het aanbod via internet toe. Hierdoor is een waardebepaling gemakkelijker: vergelijkbare dieren worden immers vaker verhandeld.

\section{Honden}

- Rashonden

Honden blijven na aanschaf door een particulier meestal tot het einde van hun leven bij de eigenaar. Veelal zijn het pups die verhandeld worden. Waardebepaling van oudere dieren is dan op grond van deze gegevens lastig omdat vergelijkbare dieren niet/zelden verhandeld worden.

- Honden voor speciaal gebruik: politiehonden, hulphonden Beveiligingshonden en politiehonden worden vaak als pup aangekocht en (hobbymatig) getraind. Na een basistraining worden deze honden ingezet voor hun werk of verder professioneel getraind. Zo'n training kan de latere gebruiker van de hond zelf op zich nemen, of dat kan plaatsvinden bij gespecialiseerde bedrijven. In het laatste geval worden de honden op het einde van de training verkocht.

Hulphonden en geleidehonden worden vaak na een basissocialisatie in gastgezinnen speciaal getraind door gespecialiseerde medewerkers van de opleidingsinstituten/stichtingen. Na deze training worden de dieren dan als hulphond bij de cliënten geplaatst maar de dieren blijven eigendom van de stichting.

\section{Postduiven}

Duiven met bijzondere prestaties of vanuit bijzondere bestanden worden onderhands, via internet sites of via (internet)veilingen verkocht. Deze dieren kunnen of in Nederland blijven of - en dan met name de zeer waardevolle dieren - aan afnemers in het buitenland verkocht.

\section{Bijzondere diersoorten en evenhoevige dierentuindieren}

Dierentuindieren worden niet onderling tussen dierentuinen verhandeld. Dierentuinen werken met fokprogramma's, die voldoen aan allerlei strenge eisen. Verkoop naar niet-dierentuinen is voor de meeste soorten uitgesloten. Doel is om genetische diversiteit te behouden. Dieren worden met gesloten beurzen uitgewisseld, niet verkocht. Voorbeelden van deze dieren zijn geit- en schaapachtigen zoals gemsbokken, waterbokken, spiesbokken en het dikhoornschaap, herten zoals lierhert en zwijnhert, gnoes, halsbandpekari (zwijn), banteng (rund) en giraffes (Burgers' Zoo, 2020). 


\subsection{Databronnen}

Gegevens voor deze korte rapportage zijn verzameld door middel van:

1. Inventarisatie van literatuur en bronnenonderzoek

- databanken en rapporten

- vakbladen en veilingsites

2. Expertconsultatie

- vertegenwoordigers van de verschillende sectoren

- taxateurs

In tabel 2.1 is per sector aangegeven welke bronnen zijn gebruikt.

Tabel 2.1 Geraadpleegde bronnen per sector

\begin{tabular}{|c|c|c|c|}
\hline & Literatuur & Databank & Experts \\
\hline Runderen & $\begin{array}{l}\text { Veeteelt } \\
\text { Interne notitie Wageningen Economic } \\
\text { Research } 2019\end{array}$ & CBS & taxateurs \\
\hline Varkens & $\begin{array}{l}\text { Interne notitie Wageningen Economic } \\
\text { Research } 2019 \\
\text { Marktprijzen fokbedrijf }\end{array}$ & CBS & R. Hoste \\
\hline Pluimvee (leg en vlees) & $\begin{array}{l}\text { Interne notitie Wageningen Economic } \\
\text { Research } 2019\end{array}$ & CBS & P. van Horne \\
\hline Paarden & $\begin{array}{l}\text { RVO } \\
\text { Nieuwe Oogst, nieuwsbericht } \\
\text { KNHS } \\
\text { Van der Peet et al. (2018) } \\
\text { Huisdierenprijzen } \\
\text { Magazine Horses (2016) } \\
\text { Hoefslag (2015) }\end{array}$ & $\begin{array}{l}\text { CBS } \\
\text { Nieuwe Oogst, } \\
\text { marktprijzen }\end{array}$ & taxateur \\
\hline Postduiven & $\begin{array}{l}\text { Feiten \& Cijfers } \\
\text { Gezelschapsdierensector } 2015 \\
\text { Duivenmarktplaats } \\
\text { Eijerkamp, sportduiven } \\
\text { Artikel jeugdjournaal } \\
\text { Artikel RTLZ } \\
\text { Artikel Quote } \\
\text { Artikel AD }\end{array}$ & & $\begin{array}{l}\text { Nederlandse } \\
\text { Postduivenhouders } \\
\text { Organisatie (NPO) }\end{array}$ \\
\hline Dierentuindieren & & & Burgers' Zoo \\
\hline
\end{tabular}




\section{Marktwaarde van de verschillende dieren}

\subsection{Landbouwhuisdieren}

\subsubsection{Rundvee}

Populatie

In 2019 waren er in Nederland 3,8 miljoen runderen op 24,6 duizend bedrijven (CBS Statline, 2020).

\section{Standaardwaarden}

De minimale waarde voor een melkkoe is de slachtwaarde. Met een gemiddelde prijs van $€ 2,40$ per kg geslacht gewicht in 2019 en een inslachting van 50\%, is de slachtwaarde van een melkkoe van $600 \mathrm{~kg} € 720$ (600 kg x 50\% x€ 2,40) (Interne notitie Wageningen Economic Research, 2019).

Voor regulier melkvee zijn er waardetabellen opgesteld. Uit deze tabellen blijkt dat in 2019 de gemiddelde melkkoe (melkgift 8.000-8.250 liter; in de 2e tot 4e lactatie) een marktwaarde van heeft $€ 1.050$ tot $€ 1$ 1.300. Dit is exclusief gezondheidstoeslagen of celgetal kortingen/toeslagen. Deze kunnen een toeslag van maximaal $€ 370$ /dier bedragen.

\section{Extreme waarden}

Hogere waarden zijn er voor hoogwaardig fokvee en KI-stieren. Deze dieren worden slechts incidenteel verkocht. Een aantal voorbeelden van hoge marktwaarden:

- De laatste jaren zijn er enkele vrouwelijke melktypische dieren verkocht met een hoge verwachtingswaarde voor een bedrag van tussen de $€ 35.000$ en $€ 80.000$.

- KI stieren hebben waarden van $€ 15.000$ tot $€ 75.000$ (persoonlijke informatie van taxateurs).

- Excellente vleesrassen hebben geen hogere marktwaarde dan de melktypische runderen. Voor fokstieren van vleesrassen worden prijzen van gemiddeld $€ 3.000$ betaald, met uitschieters naar $€ 5.600$ (Boerderij, 2017). Van een recente verkoop van een vleesstier op een Franse veiling, is bekend dat het dier $€ 15.200$ opbracht (Veeteelt, januari 2020).

\subsubsection{Varkens}

\section{Populatie}

In 2019 waren er in Nederland 12 miljoen varkens op ruim vierduizend bedrijven (CBS Statline, 2020). In de varkenshouderij gaat het voornamelijk om zeugen, biggen en vleesvarkens.

\section{Standaardwaarden}

De minimale waarde voor een zeug is de slachtwaarde: $€ 224$, dat is $€ 0,97$ per $\mathrm{kg}$ levend gewicht en $€ 0,71$ per kg geslacht gewicht (gemiddelde prijs 2019).

Ook voor reguliere varkens zijn waardetabellen opgesteld. In 2019 had de gemiddelde zeug een marktwaarde van $€ 472$ in een range van $€ 281$ tot $€ 623$, afhankelijk van het aantal worpen. Bij zeugen is uitsluitend bepaalde genetica marktwaarde-verhogend. Prijzen van zoekberen zijn gelijk aan die van slachtzeugen: $€ 0,97$ per kg levend gewicht (Interne notitie Wageningen Economic Research 2019).

De adviesprijs in week 8 (2020) voor een Topigs zeug van 28 weken oud is tussen de $€ 406$ en $€ 415$ (TN70, Topigs 20 en TN50) (Topigsnorsvin).

De waarde van biggen van $25 \mathrm{~kg}$ was in mei $2019 € 63$ (Interne notitie Wageningen Economic Research 2019), maar ligt begin 2020 op een recordhoogte van $€ 100$. (persoonlijke mededeling dhr. Hoste). 
Anno 2019 had een vleesvarken een waarde die varieerde van $€ 63$ bij opleg tot $€ 158$ bij het bereiken van het optimale slachtgewicht. Voor vleesvarkens is uitsluitend bedrijfsomvang of het houden volgens bepaalde marktconcepten (zoals biologisch) marktwaarde verhogend (Interne notitie Wageningen Economic Research 2019).

\section{Extreme waarden}

De prijs die Topigsnorsvin hanteerde in november 2019 voor bedrijfs KI beren is $€ 2.600$ per dier (Topigsnorsvin). Er zijn geen openbare bronnen met marktwaarden voor topfokdieren (deze dieren blijven vaak eigendom van fokkerijorganisaties).

\subsubsection{Pluimvee ${ }^{1}$}

\section{Populatie}

In 2019 waren er in Nederland werden op commerciële pluimveebedrijven 101 miljoen kippen, exclusief overig pluimvee, in 19 duizend bedrijven. Dat waren 44,3 miljoen leghennen, 1,6 miljoen ouderdier legrassen, 48,1 vleeskuikens en 7,1 ouderdiervleeskuikens (CBS Statline, 2020).

\section{Standaardwaarden}

In de waardetabellen voor pluimvee wordt de marktwaarde van verschillende dia categorieën en leeftijden beschreven.

De gemiddelde waarde van een vleeskuiken begint bij $€ 0,30$ voor een eendagskuiken en stijgt tot ongeveer $€ 2$ op slachtleeftijd (prijspeil 2019).

De waarde van een leghen begint bij $€ 0,60-€ 0,65$ voor een eendagskuiken en stijgt tot maximaal $€ 5$ op 23 weken leeftijd, waarna de waarde vervolgens weer zakt tot de slachtprijs van ongeveer $€$ 0,40 (Interne notitie Wageningen Economic Research 2019).

\section{Extreme waarden}

De waarde van dieren stijgt naarmate ze hoger in de pluimveepiramide staan. De pluimveepiramide is als volgt opgebouwd: onderin staan de productiedieren, een generatie hoger staan de ouderdieren, daarboven de grootouderdieren en aan de top van de piramide de overgrootouderdieren.

Voor de waarde van de dieren in de verschillende schakels van bedrijfsmatig gehouden pluimvee kan de volgende vuistregel aangehouden worden: elke stap hoger in de piramide geeft een waardevermeerdering met een factor 10.

Dat betekent dat de overgrootouderdieren van vleeskuikens (eendagskuikens) (3 schakels hoger dus een factor 1.000) een waarde van rond de $€ 300$ hebben, en de overgrootouderdieren van leghennen een waarde van rond de $€ 600$ tot $€ 650$.

De dieren boven aan de piramide betreffen de dieren uit de zuivere lijnen. Deze dieren zijn eigendom van de fokkerijorganisaties en in deze dieren vindt geen handel plaats. Van zuivere lijn topfokdieren zijn dus ook geen marktprijzen beschikbaar (mededeling dhr. Van Horne).

\subsubsection{Paarden}

\section{Populatie}

De schattingen van het aantal paarden in Nederland lopen uiteen tussen 420 en 450 duizend dieren (Wageningen Economic Research, interne notitie 2016). De meeste paarden en pony's worden op nietlandbouwbedrijven gehouden en worden niet door het CBS geregistreerd. Op landbouwbedrijven werden in 201888 duizend paarden gehouden. Dit aantal neemt steeds verder af: in 2000 waren dat er nog 117 duizend (CBS, landbouwtelling).

$\mathrm{Er}$ is een I\&R-systeem voor paarden, ingericht om dieren traceerbaar te maken in geval van bijvoorbeeld een ziekte. Traceerbaarheid heeft ook als doel om de eigenaar te helpen zijn dieren te

\footnotetext{
${ }^{1}$ Deze sectie heeft betrekking op commercieel gehouden pluimvee. Sierpluimvee wordt in sectie 3.2 .3 behandeld.
} 
identificeren (herkennen), om een afnemer van het dier garanties te geven over de herkomst en illegale en malafide handel te bestrijden. In alle gevallen is van belang dat de individuele dieren voorzien zijn van een oormerk, chip of paspoort (NVWA). Input voor dit systeem zijn de registraties van paarden en pony's door 33 in Nederland erkende paspoortuitgevende instanties. (RVO, februari 2020).

Volgens LTO zijn 10.000 bedrijven actief in de paardenhouderij. De meeste bedrijven hebben slechts enkele paarden (minder dan 20 dieren per bedrijf). Er waren in 201765 bedrijven met 100 dieren of meer. Er zijn meer dan 3.000 ruitersportcentra en -verenigingen, waarvan 1.000 maneges.

In de sport zijn verschillende disciplines te onderscheiden (waaronder dressuur, springen, western, mennen, endurance, eventing) op verschillende niveaus (van recreatie tot en met internationale sport). Het is niet bekend hoeveel paarden welke disciplines beoefenen. (Van der Peet et al., 2018).

De KNHS (Koninklijke Nederlandse Hippische Sportfederatie) rapporteert jaarlijks kerncijfers met aantal leden, aantal startpassen en aantal starts. Dit geeft een indicatie van het aantal paarden dat wedstrijden start. In 2019 zijn er bijna 58 duizend startpassen uitgegeven. Hier kunnen echter dubbeltellingen in zitten, omdat dit jaar, maand en dag startpassen betreft (KNHS, 2020).

\section{Standaardwaarden}

De waarde van slachtpaarden ligt momenteel op ongeveer $€$ 350, uitgaande van een paard van $500 \mathrm{~kg}$ met een inslachting van $50 \%$ en een kiloprijs van $€ 1,40$ (nieuwe Oogst, maart 2020). Veel paarden kunnen niet geslacht worden omdat ze tijdens het leven behandeld zijn met niet voor paarden geregistreerde medicijnen. In principe is er dan geen slachtwaarde, en is de waarde van zo'n dier $€ 0$.

De meeste paarden zijn hobby- en recreatiepaarden. Een gezond basisrecreatiepaard is te koop voor tussen de $€ 2.500$ en $€ 10.000$. Voor de eigenschappen braaf en kindvriendelijk wordt in de regel iets meer betaald. Zie voor prijzen van verschillende rassen tabel 3.1.

Tabel 3.1 Marktwaarde van een gezond(e) paard/ pony (basis recreatiepaard)

\begin{tabular}{lr} 
Ras & $\begin{array}{c}\text { Marktwaarden } \\
\text { Pony }\end{array}$ \\
\hline Appaloosa & $€ 1.150$ tot $€ 4.000$ \\
\hline Quarter & $€ 5.000$ \\
\hline Fjord & $€ 4.500$ \\
\hline Haflinger & $€ 1.200$ tot $€ 2.600$ \\
\hline Arabier & $€ 1.100$ tot $€ 2.500$ \\
\hline Fries & $€ 2.500$ tot $€ 5.000$ \\
\hline Tinker & $€ 3.750$ tot $€ 45.000$ \\
\hline IJslander & $€ 750$ tot $€ 3.400$ \\
\hline
\end{tabular}

Bron: https://www.huisdierenprijzen.nl/.

De waarde van paarden voor sport en fokkerij ligt in het algemeen hoger dan die van het basisrecreatiepaard. De prijs is afhankelijk van kwaliteit en potentie van het paard, leeftijd, gezondheid, rijdbaarheid, uiterlijk, de markt, et cetera.

Tabel 3.2 geeft prijzen van sportpaarden weer, ingeschat door paardenhandelaren. Voor een veulen met gezochte afstamming en exterieur wordt tussen de $€ 4.000$ en $€ 6.000$ betaald. Is het veulen extreem goed, dan kan de prijs oplopen tot $€$ 15.000. De verwachtingswaarde speelt hierbij een grote rol.

Van de 420 tot 450 duizend paarden en pony's, zijn er ongeveer 58 duizend die ten minste in de B-sport uitkomen (via KNHS). Deze paarden en pony's hebben een waarde vanaf $€ 2.500$ (gezond basisrecreatiepaard) tot de hoogste prijzen die betaald worden op grandprixniveau. Voor een 
springpaard, dat parcoursen van 1,45 m springt en potentie heeft tot meer, wordt $€ 20.000$ tot $€ 200.000$ betaald (Magazine Horses, 2016).

Extreme waarden

Vooral bij paarden vindt veel 'onderhandse' handel plaats. Dat kan om hele hoge bedragen gaan, echter de prijzen die voor exceptioneel goede paarden betaald worden zijn niet te achterhalen. Een van de weinige voorbeelden waarbij de prijs wel openbaar geworden is, betreft het dressuurpaard Totilas, bereden door Edward Gal in 2015. Die is voor 21 miljoen dollar verkocht (Hoefslag, 2015).

Tabel 2.2 Marktwaarde van sportpaarden afhankelijk van leeftijd, potentieel en niveau

\begin{tabular}{lllllll} 
Leeftijd & 3 jaar & 3 jaar & 4 jaar & $5 / 6$ jaar & $5 / 6$ jaar & Basispaard a) \\
Potentieel & Goed & Heel goed & Goed & Goed & Exceptioneel & Normaal \\
\hline Niveau & Onbeleerd & Onbeleerd & Zadelmak & $\mathrm{M} / \mathrm{Z}$ & $\mathrm{M} / \mathrm{Z}$ & $\mathrm{Z}$ \\
\hline Prijs in $\mathbf{C} * \mathbf{1 . 0 0 0}$ & $7-8$ & $20-40$ & $12,5-15$ & $15-20$ & geen prijzen \\
& & & & & g-20 \\
\end{tabular}

Bron: Magazine Horses (2016).

a) Leeftijd minder belangrijk.

\subsection{Bijzondere diersoorten (honden, vogels, evenhoevigen)}

\subsubsection{Honden}

\section{Populatie}

In Nederland zijn ongeveer 1,5 miljoen honden verdeeld over 18,4\% van de huishoudens (Divebo, 2019). Dit aantal komt in meerdere bronnen terug (Van der Peet et al., 2018). Hondeneigenaren hebben gemiddeld 1,2 honden. De meeste honden worden gehouden als gezelschapsdier. Overige doelen zijn politiehond, hulphond voor bijvoorbeeld blinden en slechtzienden, speurhond (bij onder andere douane) of jachthond. De aantallen dieren die in deze verschillende groepen aanwezig zijn, zijn niet bekend.

Nederland is een exporteur van wereldformaat als het gaat om politie- en speurhonden. Jaarlijks worden 800 tot 1.000 in Nederland gefokte en getrainde honden geëxporteerd. Daarnaast is er ook export van in Nederland getrainde honden die elders gefokt zijn, met name in Oost-Europa. Dat gaat jaarlijks om ongeveer 5 duizend dieren. Van al deze exporthonden (voornamelijk naar Amerika) is $60 \%$ tot $70 \%$ opgeleid als speurhond en $30 \%$ tot $40 \%$ als politiehond (mondelinge mededeling van dhr. Verbeek, Dutch K9 Centre).

\section{Standaardwaarden}

De marktwaarde van een hond is vooral zichtbaar in pup-prijzen. Dat is het moment dat honden worden verhandeld. Als ze daarna van eigenaar wisselen is dat meestal door een veranderde levenssituatie van de eigenaar, of omdat het karakter van de hond toch niet blijkt te passen. Gaat zo'n eigenaarwissel via een asiel dan kost een hond tussen de $€ 100$ en $€ 400$. Hiervoor is het dier medisch onderzocht, ingeënt, gechipt en geregistreerd (De dierenbescherming). Volwassen honden worden zelden verkocht.

Pups met als doel 'huishond' met stamboom zijn te koop vanaf $€ 450$ tot $€ 2.250$, afhankelijk van het ras. Fokhonden zijn duurder. In de literatuur wordt een voorbeeld van $€ 8.000$ genoemd voor een fokhond van een bepaald ras (huisdierenprijzen. $\mathrm{nl}$ ).

Het rapport Feiten en cijfers gezelschapsdieren 2015 meldt $€ 1.250$ voor een pup met stamboom, $€ 450$ voor een pup zonder stamboom en $€ 140$ voor een volwassen hond uit het asiel. 


\section{Extreme waarden}

De waarde van een goed getrainde politiehond ligt tussen de $€ 4.000$ en de $€ 6.000$, met uitschieters naar $€$ 8.000. De waarde van een goed getrainde speurhond (gebruik bij douanehond en defensie) ligt tussen de $€ 3.000$ en de $€ 4.000$ (mondelinge mededeling van dhr. Verbeek, Dutch K9 Centre).

Getrainde jachthonden worden in Groot-Brittannië wel volop verhandeld, in Nederland gebeurt dit nauwelijks.

Er zijn wel enkele voorbeelden bekend van zeer goed getrainde honden, die excellent presteerden in de wedstrijdsport. Een hond is voor $€ 10.000$ naar China geëxporteerd en een andere voor $€ 70.000$ naar Japan (NBG, 2020).

\subsubsection{Postduiven}

\section{Populatie}

In Nederland worden circa 2 miljoen postduiven gehouden door 15 duizend duivenliefhebbers. De gemiddelde liefhebber heeft 70-80 duiven, bij een liefhebber met grote hokken en meerdere verzorgers kan dit oplopen tot 1.000 duiven (NPO).

In Nederland zijn honderden commerciële postduivenhouders die duiven fokken voor de verkoop naar landen binnen en buiten de EU (HAS Hogeschool en Universiteit Utrecht, 2015).

\section{Standaardwaarden}

Voor hobbyhouders worden koppels jonge duiven inclusief stamboom aangeboden op duivenmarktplaats voor $€ 75$ tot $€ 100$. Per stuk variëren de vraagprijzen tussen $€ 35$ en $€ 60$. Doffers zijn iets duurder, die worden aangeboden voor prijzen tussen $€ 45$ en $€ 100$. Sportduiven worden aangeboden voor tussen $€ 750$ en $€ 3.000$ (Eijerkamp, 2020).

\section{Extreme waarden}

De afgelopen 3 jaar zijn voorbeelden bekend van duiven die voor hoge bedragen naar China zijn verkocht: $€ 360.000$ in 2017 (Jeugdjournaal, 2017), $€ 400.000$ en $€ 376.000$ in 2018 (QUOTE, 2018 en RTLZ.NL, 2019) en $€ 1.252 .000$ in 2019 (AD, 2019).

\subsubsection{Marktwaarde van siervogels}

\section{Populatie}

In Nederland wordt het aantal zang- en siervogels geschat op 3,9 miljoen in 2014. De houders van deze dieren hebben er gemiddeld 6,4 per huishouden (Van der Peet et al., 2018).

\section{Standaardwaarden}

Vogels worden vaak alleen per paar verkocht. De hier genoemde prijzen zijn per stuk. De prijzen van siervogels variëren tussen de $€ 5$ voor een Chinese Dwergkwartel, $€ 30$ voor een kanarie tot $€ 700$ voor speciale watervogels.

\section{Extreme waarden}

De hoogste waarden zijn te vinden bij de papegaaiachtigen: kaketoes, papegaaien, parkieten en lori's. Hier variëren de prijzen tussen $€ 700$ en $€ 2.850$ voor bijvoorbeeld een Molukkenkaketoe (Huisdierenprijzen).

\subsubsection{Marktwaarde van dierentuindieren}

Dierentuindieren worden niet verhandeld, dus zijn er ook geen marktwaarden. 


\section{$4 \quad$ Samenvattend}

De in de voorgaande secties besproken waarden voor diersoorten zijn in tabel 4.1 samengevat.

- Met name voor de meest waardevolle dieren zijn er beperkte reguliere markten en worden de dieren of niet of onderhands verhandeld. Het is dan ook moeilijk om van deze dieren daadwerkelijk betaalde prijzen boven water te halen. De weergegeven waarden moeten dan ook als indicatief worden beschouwd.

- Naast een handelswaarde hebben dieren ook vaak emotionele waarde voor de eigenaar. In de genoemde bedragen is deze emotionele waarde buiten beschouwing gelaten.

- Zoals uit tabel 4.1 blijkt, zijn er bij alle besproken diersoorten grote verschillen tussen de gemiddelde waarden en de extreme waarden.

Tabel 3.1 Samenvattende tabel waarde voor de verschillende diersoorten

\begin{tabular}{|c|c|c|c|c|}
\hline Diersoort & Korte omschrijving & Populatie & Gemiddelde waarde & Extreme waarden \\
\hline \multirow[t]{2}{*}{ Runderen } & Gebruiksvee & 3,8 miljoen & $€ 1.050$ tot $€ 1.670$ & - \\
\hline & Hoogwaardig vrouwelijk fokvee & $5.000-8.000$ & & $€ 35.000$ tot $€ 80.000$ \\
\hline \multirow[t]{3}{*}{ Varkens } & Gebruiksvarkens & 12 miljoen totaal & Zeug: $€ 472$ & - \\
\hline & & & Vleesvarken: $€ 158$ & - \\
\hline & & & $€ 2.600$ & \\
\hline Kippen & Leg gebruikspluimvee & 44,3 miljoen & $€ 0,60$ tot $€ 0,65$ & - \\
\hline (waarde & Leg fokpluimvee & 1,6 miljoen & $€ 6$ tot $€ 650$ & Niet bekend \\
\hline \multirow[t]{2}{*}{ eendagskuikens) } & Vlees gebruikspluimvee & 48,1 miljoen & $€ 0,30$ & - \\
\hline & Vlees fokpluimvee & 7,1 miljoen & $€ 3$ tot $€ 300$ & Niet bekend \\
\hline \multirow{2}{*}{ Paarden } & & sportpaarden en - & & \\
\hline & & pony's & & \\
\hline \multirow[t]{5}{*}{ Honden } & Rashond & 1,5 miljoen totaal & $€ 450$ tot $€ 2.250$ & $€ 8.000$ \\
\hline & & & (pupprijzen) & (fokhond) \\
\hline & Asielhond & & $€ 100$ tot $€ 450$ & - \\
\hline & Gebruikshond & & $€ 3.000$ tot $€ 6.000$ & $€ 6.000$ tot $€ 70.000$ \\
\hline & & & (getrainde hond) & getrainde hond) \\
\hline Postduiven & Basis & 2 miljoen totaal & $€ 50$ tot $€ 100$ & $€ 15.000$ tot $€ 1$ miljoen \\
\hline
\end{tabular}




\section{Literatuur en websites}

AD, 2019, Armando is de duurste Europese prijsduif ooit: 1,2 miljoen euro, https://www.ad.nl/buitenland/armando-is-de-duurste-europese-prijsduif-ooit-1-2-miljoeneuro a1b4c0063/?referrer=https://www.google.com/

Boerderij, 2017, https://www.boerderij.nl/Rundveehouderij/Foto-Video/2017/3/Blonde-stierengeveild-voor-gemiddeld-3111-112751E/

Burgers' Zoo, 2020, Mededeling van Burgers' Zoo

CBS Statline, 2020, Databank: CBS, https://opendata.cbs.nl/statline/

Divebo, 2019, Consument laat zich minder verleiden tot impulsaankoop van huisdieren, https://dibevo.nl/pers/consument-laat-zich-minder-verleiden-tot-impulsaankoop-van-huisdieren

De dierenbescherming, tips voor de baas, https://ikzoekbaas.dierenbescherming.nl/tips-voor-debaas/hond

Duivenmarktplaats, http://www.duivenmarktplaats.nl/

Eijerkamp, 2020, https://www.eijerkamp.com/en/racing-pigeons-for-sale

EU wetgeving 1, 2020, https://eur-lex.europa.eu/legalcontent/EN/TXT/HTML/?uri=CELEX:32016R0429\&from=EN\#d1e1857-1-1

EU wetgeving 2, 2020, https://eur-lex.europa.eu/legal-content/EN/TXT/?uri=CELEX\%3A32014R0652

European Commission, 2016, GUIDELINES FOR MEMBER STATES FOR EU FUNDING OF VETERINARY PROGRAMMES, https://ec.europa.eu/food/sites/food/files/safety/docs/cff_animal_vetprogs_ms_guidelines_rev2.pdf

HAS Hogeschool en Universiteit Utrecht, 2015, Feiten \& Cijfers Gezelschapsdierensector 2015 https://edepot.wur.nl/361828

Hoefslag, 2015, Top 10 duurst verkochte paarden ooit, 2015, september 2015

https://www. dehoefslag.nl/laatste-nieuws/algemeen/top-10-duurst-verkochte-paarden-ooit. html

Huisdierenprijzen, https://www.huisdierenprijzen.nl/

Jeugdjournaal, 2017, Record: duif verkocht voor 360.000 euro, https://jeugdjournaal. nl/artikel/2161375-record-duif-verkocht-voor-360-000-euro.html

Kerncijfers KNHS, KNHS, 2020, https://www.knhs.nl/over-knhs/publicaties/kerncijfers-knhs/

Magazine horses, 2016, Wat kost een goed sportpaard, https://magazine. horses. nl/magazine/paardenkrant-horses-nl-magazine-5-2016/wat-kost-eengoed-sportpaard/

Nieuwe Oogst, 2020, Rendac proef met chiplezer voor dood paard, januari 2020, https://www. nieuweoogst.nl/nieuws/2020/01/29/rendac-proef-met-chiplezer-voor-dood-paard 
Nieuwe Oogst, 2020, Marktprijzen paarden en pony's,

https://www. nieuweoogst.nl/marktprijzen/paarden-en-ponys

NVWA, https://www.nvwa.nl/onderwerpen/identificatie-en-registratie-i-r/doel-i-r

Overheid.nl, 2020, Wet Dieren https://wetten.overheid.nl/BWBR0030250/2020-01-01

Peet, van der, et al., 2018, Feiten en cijfers over de Nederlandse veehouderijsectoren 2018, WUR https://edepot.wur.nl/464128

Persoonlijke mededeling mevr. Van Berkel, secretaris Nederlandse Postduivenhouders Organisatie Persoonlijke mededeling dhr. Van Horne (Wageningen Economic Research)

Persoonlijke mededeling dhr. Hoste (Wageningen Economic Research)

Persoonlijke mededeling van de NBG, 2020 (Nederlandse Bond van Gebruikshondensportverenigingen)

Persoonlijke mededeling van rundvee taxateurs

Persoonlijke mededeling van Topigsnorsvin

Persoonlijke mededeling van dhr. Verbeek, Dutch K9 Centre http://www.dutchk9centre.nl/index.php/home

QUOTE, 2018, Rijk met duiven: 'Binnen 5 jaar is de duurste duif een miljoen euro waard', https://www.quotenet.nl/nieuws/a211481/rijk-met-duiven-binnen-5-jaar-is-de-duurste-duif-eenmiljoen-euro-waard-211481/

RTLZ.NL, 2019, Schatrijke Chinezen storten zich op 'onze' postduiven en drijven de prijs op https://www.rtlz.nl/business/ondernemen/artikel/4570156/chinezen-rijk-duiven-fortuin-kopen

RVO, februari 2020, https://www.rvo.nl/sites/default/files/2017/02/Paardenpaspoort-uitgevendeinstanties.pdf

Topigsnorsvin, https://topigsnorsvin.nl/news-archive/topigs-norsvin-referentieprijs/

Veeteelt, 2020, Limousinstier obelix verkast voor 15200 euro, januari 2020

http://www.veeteeltvlees.nl/nieuws/fokkerij/2020/limousinstier-obelix-verkast-voor-15200-euro)

Wageningen Economic Research, 2016, Verkenning aantal paarden en pony's in Nederland. Interne notitie Wageningen Economic Research

Wageningen Economic Research, 2019, Waardetabellen: melkvee, varkens, pluimvee), Interne notitie 
Wageningen Economic Research Postbus 29703

2502 LS Den Haag

T 0703358330

Ecommunications.ssg@wur.nl

www.wur.nl/economic-research

Wageningen Economic Research NOTA

2020-038
De missie van Wageningen University \& Research is 'To explore the potential of nature to improve the quality of life'. Binnen Wageningen University \& Research bundelen Wageningen University en gespecialiseerde onderzoeksinstituten van Stichting Wageningen Research hun krachten om bij te dragen aan de oplossing van belangrijke vragen in het domein van gezonde voeding en leefomgeving. Met ongeveer 30 vestigingen, 5.000 medewerkers en 12.000 studenten behoort Wageningen University \& Research wereldwijd tot de aansprekende kennisinstellingen binnen haar domein. De integrale benadering van de vraagstukken en de samenwerking tussen verschillende disciplines vormen het hart van de unieke Wageningen aanpak. 



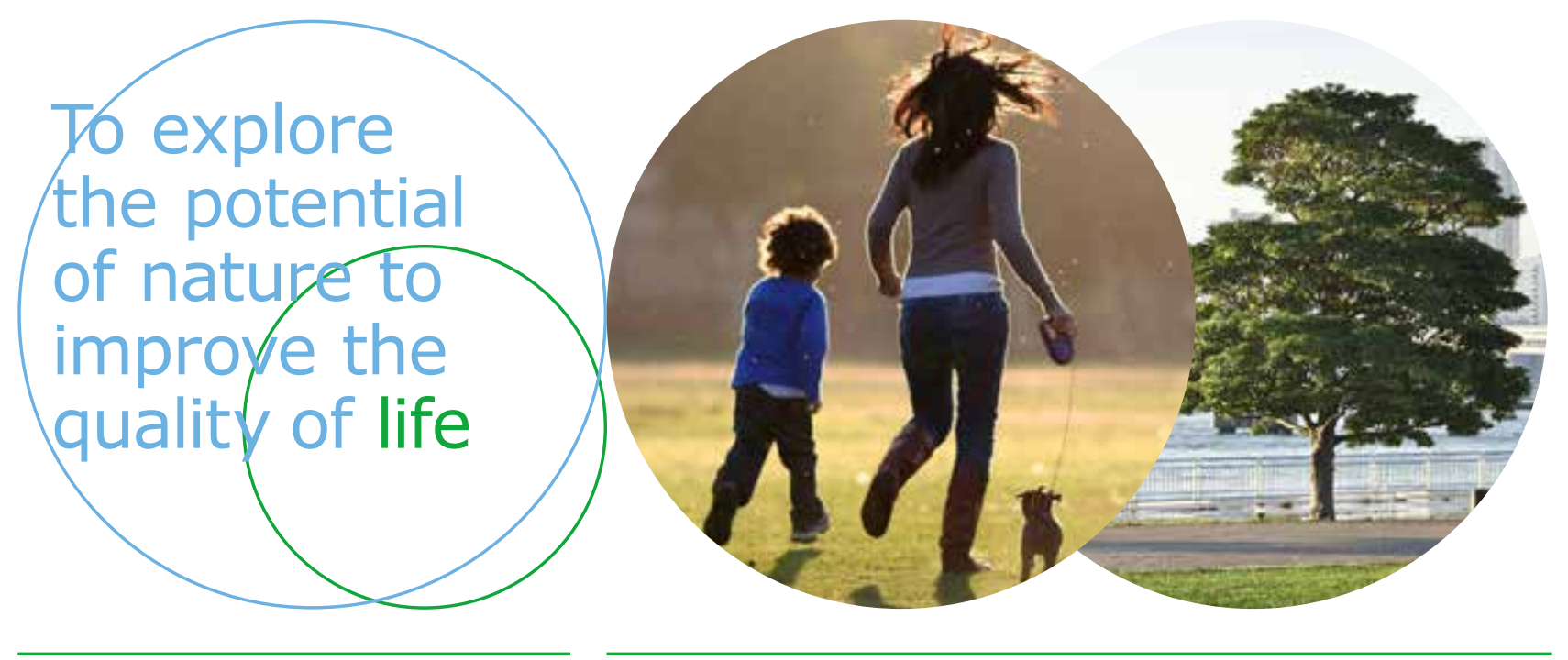

Wageningen Economic Research Postbus 29703

2502 LS Den Haag

T 0703358330

E communications.ssg@wur.nl www.wur.nl/economic-research

Nota $2020-038$
De missie van Wageningen University \& Research is 'To explore the potential of nature to improve the quality of life'. Binnen Wageningen University \& Research bundelen Wageningen University en gespecialiseerde onderzoeksinstituten van Stichting Wageningen Research hun krachten om bij te dragen aan de oplossing van belangrijke vragen in het domein van gezonde voeding en leefomgeving. Met ongeveer 30 vestigingen, 5.000 medewerkers en 12.000 studenten behoort Wageningen University \& Research wereldwijd tot de aansprekende kennisinstellingen binnen haar domein. De integrale benadering van de vraagstukken en de samenwerking tussen verschillende disciplines vormen het hart van de unieke Wageningen aanpak. 